\title{
USING COMMERCIAL ENZYME PREPARATIONS IN MALE AND FEMALE BROILERS FED LOW ENERGY DIETS
}

\section{H. M. A. Hassan, Amani W. Youssef and M. A. Mohamed}

Department of Animal Production, National Research Centre, 12622, Dokki, Egypt

\section{SUMMARY}

This study was conducted to evaluate the effect of using different commercial enzyme preparations (Xylam ${ }^{\mathbb{B}}$ and Amecozyme ${ }^{\mathbb{B}}$ ) on growth performance and carcass characteristics of male and female broiler chicks fed corn-soybean meal diets containing different levels of energy. Two basal diets were formulated, the control diets contained 3000, 3150 and $3200 \mathrm{kcal} \mathrm{ME/Kg}$ and the low energy diets contained 2850, 3000 and $3050 \mathrm{kcal} \mathrm{ME/Kg}$ for the starting (1-14d), growing (15-28d) and finishing (29-38d) periods, respectively. The control and the low energy diets were fed without and with $0.5 \mathrm{~g} / \mathrm{Kg}$ of either Xylam or Amecozyme. A total number of 540 male and 540 female one day-old Ross broiler chicks were used. Six dietary treatments were formulated. Every dietary treatment was fed to 6 replicates (15 chicks each). The results indicated the following:

(1) Male broilers fed the low energy diet without enzyme supplementation gained significantly $(P<0.05)$ more weight and consumed more feed $(P<0.05)$ for the starting and the entire periods than those fed the control diet, however, worse FCR value was obtained. Adding enzyme preparations (Amycozyme) to the control diet significantly $(P<0.05)$ improved $B W G$ and $F C R$ for the entire period compared to control diet. Adding enzyme preparations (Amycozyme) to the low energy diet significantly $(P<0.05)$ reduced $B W G$ for the starting and the entire periods compared to the low energy diet without enzyme supplementation. Adding enzyme preparations (Xylam) to the control diet did not improve $B W G$, while adding enzyme preparations $(X y l a m)$ to low energy diet significantly $(P<0.05)$ improved $B W G$ for the starting and the entire periods compared to the control diet. FCR significantly $(P<0.05)$ improved for birds fed low energy diet with enzyme supplementation compared to birds fed low energy diet without enzyme supplementation.

(2) Female broilers fed the low energy diet recorded significantly higher $(P<0.05)$ value of body weight gain and consumed more feed $(P<0.05)$ for the starting and growing periods compared to those fed the control diet. FCR recorded significantly $(P<0.05)$ the worst values for birds fed the low energy diet compared with other dietary treatments for the different intervals and the entire period. FCR significantly $(P<0.05)$ improved with birds fed enzyme supplemented diets (either the control or low energy diets) compared to those fed diets without enzyme supplementation. Birds fed diets supplemented with enzyme preparations consumed less feed and utilized feed significantly $(P<0.05)$ more efficient than those fed diets without enzyme supplementation.

(3) Carcass characteristics of male and female broilers were not affected by enzyme addition to diets. However, female chicks were able to deposit more abdominal fat than male chicks. The overall results indicated that using enzyme preparations may increase efficiency of feed utilization, as a pronounced effect of using enzyme preparations on FCR was detected particularly, on low energy diet.

Issued by The Egyptian Society of Animal Production 


\section{Keywords: Broiler performance, carcass, enzyme, low energy}

\section{INTRODUCTION}

Recently, using enzymes in poultry feed has increased greatly not only in traditional markets where wheat and barley are the principal grains, but also in countries where corn and soybean form the represent major part of poultry diets. The cell wall of these cereals is primary composed of carbohydrates complex (non starch polysaccharides, NSPs). Corn contains up to 29\% NSPs (Malathi and Devegowda, 2001). These NSPs exhibit anti-nutritional activities that negatively affect poultry performance and reducing ME content. Moreover, composition of corn can be varied from batch to batch resulting in considerable variation in its energy value for poultry (Cowieson, 2005). The presence of oligosaccharides in soybean meal such as raffinose and stachyose is partially responsible for a reduction in energy digestibility (Coon et al., 1990).

The judicious use of exogenous enzymes such as xylanase, $\beta$ - glucanase, cellulase, $\alpha$ amylase and protease are used to circumvent the adverse effect of NSPs in the diet and increase performance (Lazaro et al., 2003 and Mathlouthi et al., 2003). Also, can ameliorate the inconsistencies in the nutritional value of corn, improving body weight gain, FCR, and flock uniformity (Acamovic, 2001 and Adeola and Bedford, 2004). Some additional benefits could be due to the partial degradation of soluble glucan chain, reducing the viscosity of intestinal contents and improving nutrient absorption.

Different studies (Doglas et al., 2000; Green Wood et al., 2002 and Hong et al., 2002) demonstrated that supplementation of maize/soy diets with commercial carbohydrate/protease preparations improved digestibility, energy value of diets and broiler performance in terms of body weight and FCR. Bi Yu and Chung (2004) found that adding $\alpha$ - amylase, $\beta$ - glucanase and xylanase to broiler starter and grower corn-soybean diets of 3\% reduction in dietary ME allowed full restoration of growth performance of broilers comparable to those fed a adequate energy positive control diet.

Abudabos (2010), Balamurugan and Chandrasekaran (2010), Cao et al. (2010) and Hana et al. (2010) studied the effect of different cocktail of various enzymes on energy and consequently performance of broilers, inconsistent results were obtained. On the other hand, the feed conversion ratio of female broilers will usually be less efficient than for male birds. In this connection, Hadron and Wiedmer (2001) investigated the effect of enzyme complex on performance of male and female broilers. They found that weight uniformity was increased for male broilers when the enzyme was added to the diets, whereas no effect was observed with female broilers. Moreover, there are limiting data on using enzyme preparations on broilers fed low energy corn-SBM based diets. Therefore, the objective of this study was to investigate the effect of two different commercial enzyme preparations on growth performance and carcass characteristics of male and female broiler chicks fed cornsoybean meal diets of low energy content. 


\section{MATERIALS AND METHODS}

Two growth experiments were designed to study the effect of adding commercial enzyme preparations to diets containing different levels of energy on performance and carcass characteristics of male and female broiler chicks. Two commercial enzymes $\left(\right.$ Xylam $^{\circledR}$ and Amecozyme ${ }^{\circledR}$ ) were used in the present study. Xylam ${ }^{\circledR}$ contains amylase and xylanase, while Amecozyme ${ }^{\circledR}$ contains xylanase, protease, $\beta-$ glucanase, lipase, cellulase and amylase.

\section{Growth Assay:}

Diets were formulated based on corn and soybean meal for starting, growing and finishing periods. Formulation and nutrient composition of the experimental diets are shown in Table 1. The diets were formulated to cover the nutrient requirements of Ross broilers. The control diets were formulated to contain 3000, 3150 and 3200 $\mathrm{kcal} \mathrm{ME} / \mathrm{Kg}$ for the starter, grower and finisher diets, respectively. The low energy diets contained $150 \mathrm{kcal} \mathrm{ME} / \mathrm{Kg}$ less than the corresponding control diets $(2850$, 3000 and 3050 for the starter, grower and finisher diets, respectively). The control and the low energy diets were fed without and with $0.5 \mathrm{~g} / \mathrm{Kg}$ of either Xylam or Amecozyme. Therefore, a total of six dietary treatments were offered. The starting period lasted from 1 to 14 , the growing period from 15 to 28 and the finishing period from 29 to 38 days of age.

Table 1. Formulation and nutrient composition of the experimental diets

\begin{tabular}{lcccccc}
\hline \multicolumn{1}{c}{ Item } & \multicolumn{3}{c}{ Control diets } & \multicolumn{3}{c}{ Low energy diets } \\
& Starter & Grower & Finisher & Starter & Grower & Finisher \\
\hline Ingredients \% & & & & & & \\
Yellow corn & 46.20 & 49.25 & 54.30 & 49.00 & 52.00 & 58.30 \\
Soybean meal (44\%) & 44.00 & 40.00 & 35.00 & 44.00 & 40.00 & 34.00 \\
Vegetable oil & 5.60 & 7.00 & 7.00 & 2.80 & 4.25 & 4.00 \\
Limestone & 1.10 & 1.00 & 1.00 & 1.10 & 1.00 & 1.00 \\
Dicalcium phosphate & 2.00 & 1.80 & 1.80 & 2.00 & 1.80 & 1.80 \\
Vit. and Min. mix ${ }^{(1)}$ & 0.30 & 0.30 & 0.30 & 0.30 & 0.30 & 0.30 \\
NaCl & 0.35 & 0.35 & 0.35 & 0.35 & 0.35 & 0.35 \\
L-Lysine HCl & 0.10 & 0.00 & 0.00 & 0.10 & 0.00 & 0.00 \\
DL-Methionine & 0.35 & 0.30 & 0.25 & 0.35 & 0.30 & 0.25 \\
Total & $\mathbf{1 0 0}$ & $\mathbf{1 0 0}$ & $\mathbf{1 0 0}$ & $\mathbf{1 0 0}$ & $\mathbf{1 0 0}$ & $\mathbf{1 0 0}$ \\
Calculated Composition & & & & & & \\
(2) & & & & & & \\
Crude protein & 23.50 & 21.92 & 20.00 & 23.70 & 22.00 & 20.00 \\
ME (Kcal/Kg) & 3000 & 3150 & 3200 & 2850 & 3000 & 3050 \\
Lysine & 1.50 & 1.31 & 1.18 & 1.50 & 1.31 & 1.18 \\
Methionine + Cystine & 1.10 & 1.01 & 0.87 & 1.10 & 1.01 & 0.87 \\
Calcium & 1.00 & 0.93 & 0.91 & 1.00 & 0.93 & 0.91 \\
Nonphytate P & 0.52 & 0.48 & 0.47 & 0.52 & 0.48 & 0.47 \\
\hline
\end{tabular}

${ }^{(1)}$ Vitamin - mineral mixture supplied per Kg of diet: Vit A, 12000 I.U; Vit D 2200 I.U; Vit E, 10 mg; Vit $\mathrm{K}_{3}, 2 \mathrm{mg}$; Vit $\mathrm{B}_{1}, 1 \mathrm{mg}$; Vit $\mathrm{B}_{2}, 4 \mathrm{mg}$; Vit $\mathrm{B}_{6}, 1.5 \mathrm{mg}$; Vit $\mathrm{B}_{12}, 10 \mu \mathrm{g}$; Niacin, $20 \mathrm{mg}$; Pantothenic acid, $10 \mathrm{mg}$; Folic acid, $1 \mathrm{mg}$; Biotin, $50 \mu \mathrm{g}$; Choline chloride, $500 \mathrm{mg}$, Copper, $10 \mathrm{mg}$; Iodine, 1mg; Iron, $30 \mathrm{mg}$; Manganese, $55 \mathrm{mg}$; Zinc, $50 \mathrm{Mg}$ and Selenium, $0.1 \mathrm{mg}$.

${ }^{(2)}$ Calculated values based on feed composition Tables of NRC (1994) 
Five hundred and forty male and five hundred and forty female of one-d-old Ross broiler chicks obtained from a commercial hatchery were used. Every dietary treatment was fed to 6 replicates of 15 chicks each. Replicates were randomly allocated in batteries of three-tier system divided into 72 compartments, 36 compartments (6 replicates X 6 dietary treatments) for male and the same for female. Birds were brooded in warmed fumigated brooder house and fed the dietary treatments. Gas heaters were used to keep the required temperature for the brooding period and light was provided $23 \mathrm{hr}$ daily during the experiment. Feed and water were allowed for ad libitum consumption. After fasting overnight, birds were weighed and feed consumption was recorded per replicate for the starting, growing and finishing periods at 14, 28 and 38 days of age, respectively. Body weight gain and feed conversion ratio were then calculated.

\section{Carcass Assay:}

At day 38, six representative chicks with body weight close to the group average were selected from each group and slaughtered for carcass characteristics. Chicks were fasted for approximately $12 \mathrm{hr}$ to empty their alimentary tract and then individually weighed, slaughtered, feathered and eviscerated. Weights of carcass, liver, heart and gizzard were recorded. The fat surrounding the gizzard and the abdominal fat were removed and weighed. The percentage of carcass, organs and abdominal fat to live body weight was calculated.

Data were statistically analyzed for analysis of variance using the General Linear Model of SAS (1990). One way analysis of variance was used according to the following model: $Y \mathrm{ij}=\mu+\mathrm{Zi}+$ Eij

Where: $\mu=$ general mean

$\mathrm{Zi}=$ effect of treatment (enzyme)

Eij= experimental error.

Significant differences among treatment means were separated by Duncan's multiple rang test (Duncan, 1955) with a 5\% level of probability.

\section{RESULTS}

The results of male broiler performance as affected by dietary treatments are shown in Table 2. A trend was recorded on such parameters (BWG, FI and FCR) for the different growth intervals (starting, growing and finishing) and the entire period (1-38 days of age). Birds fed the low energy diet without enzyme supplementation gained significantly $(\mathrm{P}<0.05)$ more weight and consumed more feed $(\mathrm{P}<0.05)$ than those fed the control diet at the starting and the entire periods. Meanwhile, worse FCR value was obtained for birds fed the low energy diet without enzyme supplementation for different growth intervals and the entire periods. For the entire period, birds fed the control diet recorded FCR value being 1.53 compared to 1.57 for those fed the low energy diet. Adding enzyme preparations (Amycozyme) to the control diet significantly $(\mathrm{P}<0.05)$ improved $\mathrm{BWG}$ for the starting and the entire periods compared to control diet. Adding enzyme preparations (Amycozyme) to the low energy diet significantly $(\mathrm{P}<0.05)$ reduced $\mathrm{BWG}$ for the starting and the entire periods compared to the low energy diet without enzyme supplementation. Adding enzyme preparations (Xylam) to the control diet did not improve BWG, while adding enzyme preparations $(X y l a m)$ to low energy significantly $(\mathrm{P}<0.05)$ improved $\mathrm{BWG}$ 
for the starting and the entire periods compared to the control diet. Values of FCR were significantly $(\mathrm{P}<0.05)$ improved for birds fed low energy diet with enzyme supplementation compared to birds fed the low energy diet without enzyme supplementation. No significant differences were observed on FCR between birds fed control or low energy diet with enzyme supplementation for the different growth intervals. Birds fed the control or low energy diet supplemented with the enzyme preparations gave 1.51 FCR value for the entire period compared to 1.53 for those fed the control diet and 1.57 for those fed the low energy diet. These results indicated that using enzyme preparations may increase efficiency of feed utilization. Pronounced effect of using enzyme preparations on FCR was detected particularly, on low energy diet.

The results of female broiler performance as affected by dietary treatments are shown in Table 3. Birds fed the low energy diet showed significant higher $(\mathrm{P}<0.05)$ value of body weight gain and consumed more feed $(\mathrm{P}<0.05)$ at the end of the starting and growing periods, compared to those fed the control diet. Feed conversion ratio recorded significantly $(\mathrm{P}<0.05)$ the worst values for birds fed the low energy diet compared with other dietary treatments for the different intervals and the entire periods. This means that although, birds fed the low energy diet gained more weight, it utilized feed less efficiently than those fed the control diet. Adding enzyme preparations to low energy or control diets significantly $(\mathrm{P}<0.05)$ decreased $\mathrm{BWG}$ value recorded for the starting and entire periods. No significant effect of enzyme addition to control diet on BWG had been observed for growing and finishing periods. Significant $(\mathrm{P}<0.05)$ effect of enzyme addition to low energy diet on $\mathrm{BWG}$ was observed only for finishing period. However, birds fed diets supplemented with enzyme preparations consumed less feed but more efficient $(\mathrm{P}<0.05)$ than those fed diets without enzyme supplementation. Values of FCR were significantly $(\mathrm{P}<0.05)$ improved for birds fed enzyme preparations supplemented diets (either the control or low energy diets) compared to those fed diets with no enzymes. No significant differences were observed on FCR between birds fed control or low energy diet with enzyme supplementation for the different growth intervals and entire periods. Birds fed the enzyme supplemented diets gave FCR values for the entire period ranged from 1.55 to 1.53 compared to the values of 1.57 to 1.59 recorded for those fed the control and low energy diets without enzyme supplementation, respectively.

The results suggested that not only extra energy was released from the diet by the action of enzyme preparation, but also more protein and amino acids were utilized by birds resulting better FCR.

Table 4 presents the effect of dietary treatments on carcass characteristics of male and female broilers at 38 days of age. No significant differences were detected among the different treatments on dressing, liver, heart, gizzard and abdominal fat weights (as \%of LBW). Though, energy level and enzyme supplementation were of no effect upon such criteria. Dressing and liver weights showed the same values for males and females being 73 and $2.39 \%$, respectively. Weights of abdominal fat of males varied from 0.90 to $1.19 \%$ with an average of $1.05 \%$. Female abdominal fat varied from 1.32 to $1.43 \%$ with an average of $1.38 \%$. It could be concluded that enzyme supplementation did not affect carcass characteristics of male and female broilers. However, female chicks were able to deposit abdominal fat more than male chicks. 
Hassan et al. 


\section{DISCUSSION}

The obtained data reveals that decreasing dietary energy level by $150 \mathrm{kcal} / \mathrm{kg}$ led the chicks, male and female, to eat more feed and gained more weight but with less efficiency of feed utilization. These results disagreed with those of Ao et al. (2009) who found that decreasing dietary energy level resulted in a significant $(\mathrm{P}<0.05)$ decrease on body weight, increase in feed intake and worse gain to feed ratio. However, Bi-Yu and Chung (2004) found that broilers fed reduced energy diet had similar weight gain as those fed the adequate energy diet. In comparison to female, male broilers had increased body weight $(+11.7 \%)$ higher feed consumption $(+9.2 \%)$ and improved FCR $(-1.9 \%)$. The current results varied from those of Hadron and Wiedmer (2001) who found that male broilers had increased body weight $(+16.3 \%)$, higher feed consumption $(+12.9 \%)$ and improved FCR(- 3.1\%) than female. Feed conversion ratio of female broilers will usually be higher (less efficient) than for male birds of corresponding weight. Feed intake decreased by enzyme addition might be attributed to birds fulfilling their nutrient requirement by taking less amount of feed due to changes in the digestibility of energy and amino acids rather than improved digestible nutrient intake. The lack of response might also be attributed to the possibility that the diets fed were extremely of good quality and allowed the birds to perform close to their genetic potential (Acamovic, 2001).

The data showed that carcass characteristics were not affected by enzyme addition to diets, except for fat weight and fat percentage. Fat deposition slightly $(\mathrm{P}>0.05)$ decreased with the addition of enzyme preparation on either male or female birds. This result is in agreement with Woodward et al. (1988) who found that chicks fed kemzyme showed the lowest average of absolute and proportional weights of abdominal fat. On the other side, Shafiee et al. (2006) found that adding biozyme (betaine, xylanase and alpha-amylase) to broiler diets resulted in heavier weight of breast, thigh and abdominal fat. Abudabos (2010) reported that commercial enzymes ( $\beta$-pentosanase, $\alpha$-amylase, glucanases, and galactomannases) supplementation to corn soybean meal broiler diets was of no significant effect on carcass parts (abdominal fat, gizzard and liver). Regarding to the results of performance and carcass characteristics, female birds utilized feed less efficiently and deposited more fat in the carcass than male.

Adding enzyme preparations to low energy or control diets enhance FCR. The use of amylase in broiler diets lead to improving starch digestion in small intestine and enhancing nutrient use (Sheppy, 2001). Added amylase complements the activity of endogenous amylase and so reducing its endogenous synthesis by the pancreas (Gracia, et al., 2003) and therefore, saving energy which becomes more available for growth. The use of xylanase may have beneficial effects as it promotes changes in the cell wall architecture by hydrolyzing the structural of arabinozylans that encapsulate nutrients and enhance their utilization (Cowieson, 2005). The effect of xylanase can be better evidenced when associated with other exogenous enzymes such as protease, amylase and phytase. Numerous studies (Kocher et al., 2003, Bi-Yu and Chung, 2004, Cowieson and Adeola, 2005, Balamurugan and Chandrasekaran 2010, and Cao et al., 2010) have shown that adding exogenous enzymes to cereal based diets enhanced nutrient availability. There are two main ways in which this occurs. First, adding enzymes to the diet can enhance the bird's own digestive enzyme capacity. 
Second, cereals grain contain many long chain carbohydrates molecules (e.g. starch, cellulose and other NSP) in plant cell, these are mainly in the cell wall where they are bond together in complex matrix, this makes them relatively in accessible to enzyme secreted by bird's digestive tract. Adding exogenous enzymes to the feed unlocks more of this potential by opening up the structures and increasing the accessibility to digestive enzymes (Adams, 2000). It appears that the presence of amylase and xylanase are helping to expose the starch more rapidly to small intestinal digestion and in doing so this may indirectly aid fat digestion as well. The protease may be aiding in corn-protein dissolution and as a result is exposing protein encrusted starch granules more rapidly to digestion. In this connection, Cowieson and Adeola (2005) reported a linear increase in the weight gain of chicks in response to cocktail enzyme (carbohydrases, protease and phytase) supplementation. Moreover, Balamurugan and Chandrasekaran (2010) studied the effect of using NSP hydrolyzing enzyme (500 and $1000 \mathrm{~g} /$ ton) on the performance of broiler and found that feed efficiency was significantly $(\mathrm{P}<0.05)$ better comparing with the control diet. Cao et al. $(2010)$ showed that addition of xylanase and phytase to corn-soy based diet improved energy, Ca and $\mathrm{P}$ utilization and consequently increased weight gain of broilers.

Feed conversion ratio was improved by enzyme addition, which is in agreement with recent reports (Lee et al., 2010 and Nian et al., 2011). Lee et al. (2010) reported that body weight gain and feed conversion ratio during the finisher period (22-32 d) and the entire experimental period $(1-32 \mathrm{~d})$ was significantly $(\mathrm{p}<0.05)$ improved in chicks that were fed low energy diets containing multiple enzymes than those received the control diets without multiple enzymes supplementation. Nian et al. (2011) showed that supplementation of xylanase had no effect $(p>0.05)$ on the weight gain and feed intake of broilers. But, FCR was improved $(p<0.05)$ by $4.3 \%$ with supplemental Xylanase. The improvement in feed conversion ratio observed in this study is likely to be a result of the improved nutrient and energy utilization. On the other hand, Hana et al. (2010) studied the effect of commercial multienzyme feed additives contain protease, alpha amylase, pectinase, phytase, gluco amylase and cellulose on the performance of broilers. The data showed that enzyme supplementation to diets were not effective in improving the performance of birds and no significant differences $(\mathrm{P}>0.05)$ were reported for heart, gizzard and abdominal fat pad weights.

The effect of age of birds on the response to exogenous enzyme addition has been also studied. Mahagna et al. (1995) reported that exogenous enzymes used in the diet of young chicken would be very beneficial in improving nutrient digestibility in at least 2 ways: 1) by supplying enzymes that chick can not produce in sufficient quantity by it self, or 2) even though the chick can produce enough of an enzyme by itself, however, exogenous enzymes may reduce the requirement for the enzyme thus making more nutrients and energy available for growth of the chick at that critical stage. Olukosi et al. (2007) found that chicks benefited more from the enzyme addition at younger age and that contribution of the enzyme to nutrient retention decrease with age in chickens.

In general, it could be concluded that adding multi-enzyme preparations to corn soybean meal broiler diets containing low energy level may increase efficiency of feed utilization. 


\section{REFERENCES}

Abudabos A., 2010. Enzyme supplementation of corn-soybean meal diets improves performance in broiler chicken. International Journal of Poultry Science, 9 (3):292-297.

Acamovic T., 2001. Commercial applications of enzymes technology for poultry production. World's Poult. Sci., 57: 225-234.

Adams 2000. Enzymes are important components in antibiotic-free poultry feeds. World Poultry Vol. 16. No. 8.

Adeola O. and M.R. Bedford, 2004. Exogenous dietary zylanase ameliorates viscosity-induced anti-nutritional effects in wheat based diets for white pekin ducts (Anas platyrinchos domesticus). Br. J. Nutr., 92: 87-94.

Ao T., A.H. Cantor, A.J. Pescatore, M.J.J. Ford, L. Pierce and K.A. Dawson, 2009. Effect of enzyme supplementation and acidification of diets on nutrient digestibility and growth performance of broiler chicks. Poult. Sci., 88(1):111-117.

Balamurugan R. and D. Chandrasekaran, 2010. Effect of multienzyme supplementation on weight gain, feed intake, feed efficiency and blood glucose in broiler chickens. Indian Journal of Science and Technology, Vol. 3 No. 2: 193195.

Bi Yu and T.K Chung, 2004. Effects of multiple-enzyme mixtures on growth performance of broilers fed corn-soybean meal diets. J. Appl. Poult. Res., 13: 178-182.

Cao P.H., F. D. Li, Y.F. Li, Y.J. Ru, A. Peron, H. Schulze and H. Bento, 2010. Effect of essential oils and feed enzymes and nutrient utilization in broilers fed a corn/soy-based diet. International Journal of Poultry Science, 9 (8):749 -755.

Coon C.N., K.L. Leske, O. Akavanichan and T.K. Cheng, 1990. Effect of oligosaccharide-free soybean meal on true metabolizable energy and fiber digestion in adult roosters. Poult. Sci., 69: 787-793.

Cowieson A. J., 2005. Factors that affect the nutritional value of maize for broilers. Poult. Sci., 84: 193-205.

Cowieson A. J. and O. Adeola, 2005. Carbohydrases and protease and phytase have an additives beneficial effect in nutritionally marginal diets for broiler chicks. Poult. Sci., 84: 1860-1867.

Doglas M.W., C. M. Parsons and M.R. Bedford, 2000. Effect of various soybean meal sources and Avizyme on chick growth performance and ileal digestible energy. J. Appl. Poult. Res., 9:74-80.

Duncan D. B., 1955. Multiple Range and Multiple F Tests. Biometric, 11: 1- 42.

Gracia M.I., M.J. Aranibar, R. Lazaro, P. Medel and G.G. Mateos, 2003. $\alpha$ amylase supplementation of broiler diets based on corn. Poult. Sci., 82: 436-442.

Green Wood M.W., C.A. Fritts and P.W. Waldroup, 2002. Utilization of Avizyme 1502 in corn-soy meal broiler diets with and without antibiotics. Poult. Sci., $91^{\text {st }}$ Annual meeting Abstracts 23, p.p: 116.

Hadron R., and H. Wiedmer, 2001. Effect of an enzyme complex in a wheat-based diets on performance of male and female broilers. J. Appl. Poult. Res., 10: 340346.

Hana A.H., A.R. Mohammad and A. Majdi, 2010. The influence of supplemental multienzyme feed additive on the performance, carcass characteristics and meat 
quality traits of broiler chickens. International Journal of Poultry Science, 9:126133.

Hong D., H. Burrows and O. Adeola, 2002. Addition of enzymes to starter and 2 grower diets for ducks. Poult. Sci., 81:1842-1849.

Kocher A.M., M. Choct, J. Ross, J. Broz and T.K. Chung, 2003. Effect of enzyme combination on AME of corn- SBM based diet in broilers. J. Applied Poult. Res., 12: $275-283$.

Lazaro R., M. Gracia, M.J. Aranibar and G.G. Mateos, 2003. Effect of enzyme addition to wheat-barley and rye basal diets on nutrient digestibility and performance of laying hens. Br. Poult. Sci., 44: 256-265.

Lee S.Y., J.S. Kim, J. M. Kim, B.K. An and C.W. Kang, 2010. Effects of Multiple Enzyme (ROVABIO ${ }^{\circledR}$ Max) Containing Carbohydrolases and Phytase on Growth Performance and Intestinal Viscosity in Broiler Chicks Fed Corn-Wheat-Soybean Meal Based Diets. Asian-Aust. J. Anim. Sci. Vol. 23, No. 9: 1198 - 1204.

Mahagna M., I. Nir, M. Larbier and Z. Nitsan, 1995. Effect of age and exogenous amylase and protease on development of the digestive tract, pancreatic enzyme activities and digestibility of nutrients in young meat type chicks. Reprod. Nutr. Dev. 35: 201-212.

Malathi V. and G. Devegowda, 2001. In vitro evaluation of non-starch polysaccharides digestibility of feed ingredients by enzymes. Poult. Sci., 80: 302305.

Mathlouthi N., M.A. Mohamed and M. Larbier, 2003. Effect of enzyme preparation containing xylanase and $\beta$-glucanase on performance of laying hens fed wheat/barley or maize /soybean meal -based diets. Br. Poult. Sci., 44: 60-66.

National Research Council, 1994. Nutrient Requirements of Poultry, $9^{\text {th }}$ revised ed. National Academy Press Washington, D.C., U.S.A

Nian F., Y. M. Guo, Y.J. Ru1, F.D. Li and A. Péron, 2011. Effect of Exogenous Xylanase Supplementation on the Performance, Net Energy and Gut Microflora of Broiler Chickens Fed Wheat-based Diets. Asian-Aust. J. Anim. Sci. Vol. 24, No. 3: $400-406$.

Olukosi O.A., A.J. Cowieson and O. Adeola, 2007. Age related influence of a cocktail of xylanase, amylase and protease or phytase individually or in combination in broilers. Poult. Sci., 86: 77-86.

SAS Institute, 1990. SAS ${ }^{\circledR} /$ STAT User's Guide: Statistics. Version 6, $4^{\text {th }}$ Edition . SAS Institute Inc, Cary, NC.

Shafiee T., N. Dabiri., M. J. Agah and H. Norollah, 2006. Effect of pellet and mash diets associated with biozyme enzyme on broiler performance. International $\mathrm{J}$. Poult. Sci., 5: 485-490.

Sheppy C., 2001. The current feed enzyme market and likely trends. In: Bedford MR, Partridge GG. Enzymes in farm nutrition. Londres: Cab International. p. 1-10.

Woodward S.A., R.H. Harmis, R.D. Miles, D.M. Janky and N. Ruiz, 1988. Influence of virginiamycin yield of broilers fed four levels of energy. Poult. Sci., 67: 12221224. 
إستخدام مستحضرات إنزيمية تجارية لذكور وإناث كتاكيت اللحم المغذاة على علائق منخفضة فى الطاقة

حسين محمد أحمد حسن، أماني وجيه يوسف، محمد أمين محمد

قسم الإتتاج الحيوانسي ، المركز القومي للبحوث، اللدقي، مصر

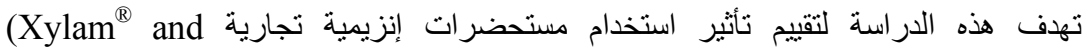

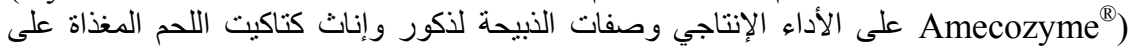

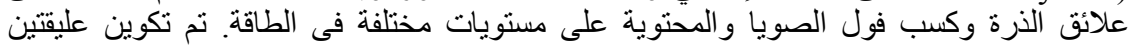

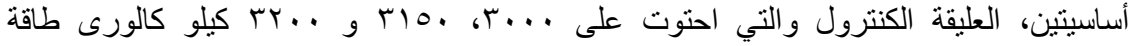

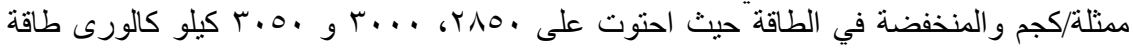

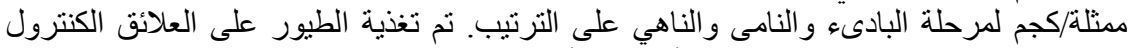

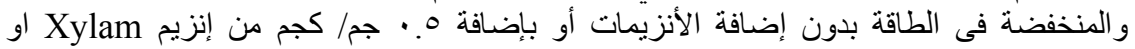
. Amecozyme

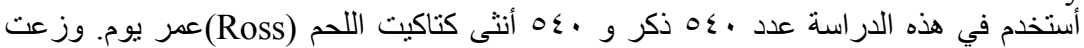

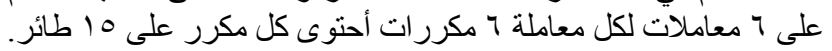

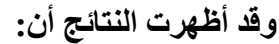

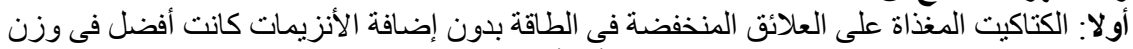

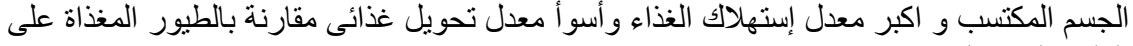
العليقة الكنترول. - الكني إضافة انزيم Amecozyme الى العليقة الكنترول أدت إلى تحسن فى وزن الجسم المكتسب و

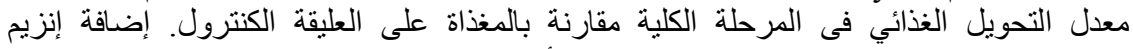

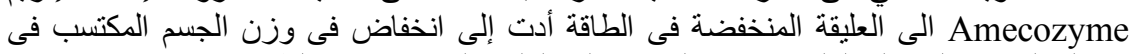

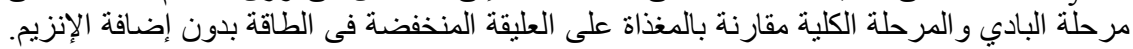

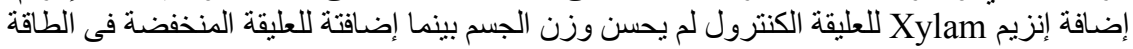

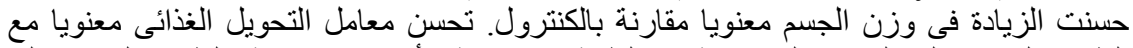

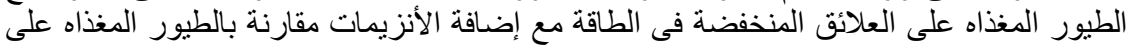

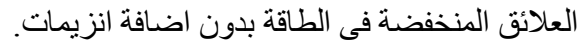

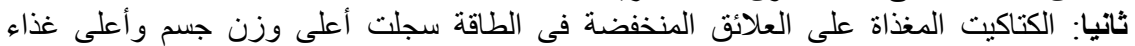

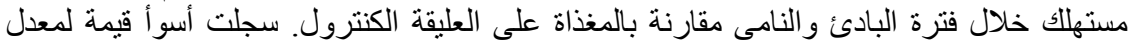

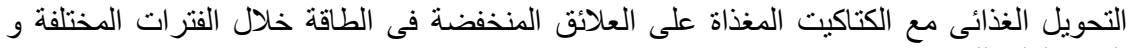
الفترة الكلية للتجربة.

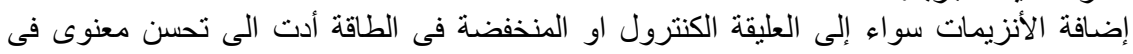

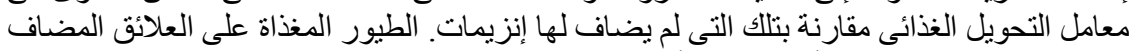

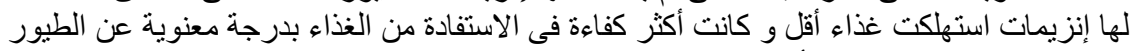

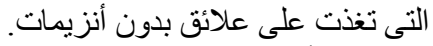

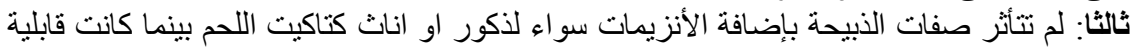
الإناث لترسيب الدهن أكثر من الذكور.

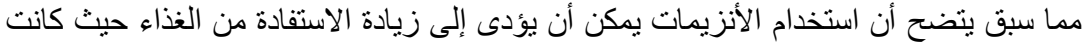
أفضل قيم معامل التحويل الغذائي خاصة مع العلائق المنخفضة فئ الطئ الطاقة. 
Table 2. Effect of enzyme supplementation on male broiler performance from 1 to 38 days of age

\begin{tabular}{|c|c|c|c|c|c|c|c|c|c|c|c|c|}
\hline \multirow{3}{*}{ Item } & \multicolumn{3}{|c|}{$\begin{array}{l}\text { Starting period } \\
\text { (1-14 days) }\end{array}$} & \multicolumn{3}{|c|}{$\begin{array}{l}\text { Growing period } \\
\text { (15-28 days) }\end{array}$} & \multicolumn{3}{|c|}{$\begin{array}{l}\text { Finishing period } \\
\text { (29-38 days) }\end{array}$} & \multicolumn{3}{|c|}{$\begin{array}{l}\text { Overall period } \\
\text { (1-38 days) }\end{array}$} \\
\hline & BWG & FI & FCR & BWG & FI & FCR & BWG & FI & FCR & BWG & FI & FCR \\
\hline & $\mathrm{g}$ & g & $\mathrm{g} / \mathrm{g}$ & $\mathrm{g}$ & $\mathrm{g}$ & $\mathrm{g} / \mathrm{g}$ & $\mathrm{g}$ & $\mathrm{g}$ & $\mathrm{g} / \mathrm{g}$ & $\mathrm{g}$ & $\mathrm{g}$ & $\mathrm{g} / \mathrm{g}$ \\
\hline \multicolumn{13}{|l|}{$\begin{array}{l}\text { Dietary } \\
\text { Creatments }\end{array}$} \\
\hline Control & $267^{\mathrm{c}}$ & $351^{\mathrm{b}}$ & $1.32^{\mathrm{ab}}$ & 886 & $1237^{\mathrm{b}}$ & $1.40^{\mathrm{b}}$ & 539 & $993^{\mathrm{ab}}$ & $1.84^{\mathrm{ab}}$ & $1691^{\mathrm{d}}$ & $2582^{\mathrm{bc}}$ & $1.53^{\mathrm{b}}$ \\
\hline Control +xylam & $268^{c}$ & $352^{\mathrm{b}}$ & $1.31^{\mathrm{b}}$ & 883 & $1222^{\mathrm{b}}$ & $1.38^{\mathrm{b}}$ & 546 & $982^{\mathrm{b}}$ & $1.80^{\mathrm{c}}$ & $1697^{\mathrm{cd}}$ & $2557^{\mathrm{c}}$ & $1.51^{\mathrm{c}}$ \\
\hline Control +amycozyme & $282^{b}$ & $368^{b}$ & $1.30^{\mathrm{b}}$ & 899 & $1256^{\mathrm{b}}$ & $1.40^{\mathrm{b}}$ & 544 & $985^{\mathrm{ab}}$ & $1.81^{\mathrm{bc}}$ & $1725^{\mathrm{b}}$ & $2609^{\mathrm{bc}}$ & $1.51^{\mathrm{c}}$ \\
\hline Low energy & $296^{\mathrm{a}}$ & $396^{\mathrm{a}}$ & $1.34^{\mathrm{a}}$ & 910 & $1335^{\mathrm{a}}$ & $1.47^{\mathrm{a}}$ & 544 & $1013^{\mathrm{a}}$ & $1.87^{\mathrm{a}}$ & $1751^{\mathrm{a}}$ & $2743^{\mathrm{a}}$ & $1.57^{\mathrm{a}}$ \\
\hline Low energy + xylam & $304^{\mathrm{a}}$ & $398^{\mathrm{a}}$ & $1.31^{\mathrm{b}}$ & 899 & $1244^{\mathrm{b}}$ & $1.38^{\mathrm{b}}$ & 550 & $990^{\mathrm{ab}}$ & $1.80^{\mathrm{c}}$ & $1753^{\mathrm{a}}$ & $2633^{\mathrm{b}}$ & $1.50^{\mathrm{c}}$ \\
\hline Low energy + amycozyme & $270^{\mathrm{c}}$ & $353^{\mathrm{b}}$ & $1.31^{\mathrm{b}}$ & 893 & $1242^{\mathrm{b}}$ & $1.39^{\mathrm{b}}$ & 548 & $989^{\mathrm{ab}}$ & $1.81^{\mathrm{bc}}$ & $1711^{\mathrm{bc}}$ & $2585^{\mathrm{bc}}$ & $1.51^{\mathrm{c}}$ \\
\hline Overall means & 281 & 369 & 1.32 & 895 & 1256 & 1.40 & 545 & 992 & 1.82 & 1721 & 2618 & 1.52 \\
\hline SE of means & \pm 3.76 & \pm 5.37 & \pm 0.01 & \pm 4.59 & \pm 10.63 & \pm 0.01 & \pm 2.31 & \pm 3.75 & \pm 0.01 & \pm 8.13 & \pm 16.58 & \pm 0.01 \\
\hline Significances & * & * & * & NS & * & * & NS & * & * & $*$ & $*$ & * \\
\hline
\end{tabular}

a-d Mean within each column with no common superscript differ significantly $(\mathrm{P}<0.05)$.

* $\mathrm{P}<0.05$ NS: not significant 
Table 3. Effect of enzyme supplementation on female broiler performance from 1 to 38 days of age

\begin{tabular}{|c|c|c|c|c|c|c|c|c|c|c|c|c|}
\hline \multirow{2}{*}{ Item } & \multicolumn{3}{|c|}{$\begin{array}{l}\text { Starting period } \\
\text { (1-14 days) }\end{array}$} & \multicolumn{3}{|c|}{$\begin{array}{l}\text { Growing period } \\
\text { (15-28 days) }\end{array}$} & \multicolumn{3}{|c|}{$\begin{array}{l}\text { Finishing period } \\
\text { (29-38 days) }\end{array}$} & \multicolumn{3}{|c|}{$\begin{array}{l}\text { Overall period } \\
\text { (1-38 days) }\end{array}$} \\
\hline & $\underset{\mathrm{g}}{\mathrm{BWG}}$ & $\underset{\mathrm{g}}{\mathrm{FI}}$ & $\begin{array}{c}\text { FCR } \\
\mathrm{g} / \mathrm{g}\end{array}$ & $\underset{\mathrm{g}}{\mathrm{BWG}}$ & $\underset{\mathrm{g}}{\mathrm{FI}}$ & $\begin{array}{c}\text { FCR } \\
\mathrm{g} / \mathrm{g}\end{array}$ & $\underset{\mathrm{g}}{\mathrm{BWG}}$ & $\begin{array}{c}\mathrm{FI} \\
\mathrm{g}\end{array}$ & $\begin{array}{c}\text { FCR } \\
\mathrm{g} / \mathrm{g}\end{array}$ & $\underset{\mathrm{g}}{\mathrm{BWG}}$ & $\begin{array}{c}\mathrm{FI} \\
\mathrm{g}\end{array}$ & $\begin{array}{c}\text { FCR } \\
\mathrm{g} / \mathrm{g}\end{array}$ \\
\hline \multicolumn{13}{|l|}{ Dietary treatments } \\
\hline Control & $279^{\mathrm{b}}$ & $374^{\mathrm{b}}$ & $1.34^{\mathrm{b}}$ & $795^{\mathrm{bc}}$ & $1176^{\mathrm{b}}$ & $1.48^{\mathrm{b}}$ & $487^{\mathrm{ab}}$ & 902 & $1.86^{\mathrm{b}}$ & $1561^{\mathrm{ab}}$ & $2452^{a b}$ & $1.57^{\mathrm{b}}$ \\
\hline Control +xylam & $223^{d}$ & $292^{\mathrm{d}}$ & $1.31^{\mathrm{c}}$ & $776^{\mathrm{c}}$ & $1125^{\mathrm{b}}$ & $1.45^{\mathrm{c}}$ & $493^{\mathrm{ab}}$ & 897 & $1.82^{\mathrm{c}}$ & $1491^{\mathrm{c}}$ & $2314^{\mathrm{c}}$ & $1.55^{\mathrm{c}}$ \\
\hline $\begin{array}{l}\text { Control } \\
\text { +amycozyme }\end{array}$ & $243^{c}$ & $321^{\mathrm{c}}$ & $1.32^{\mathrm{bc}}$ & $787^{\mathrm{bc}}$ & $1134^{\mathrm{b}}$ & $1.44^{\mathrm{c}}$ & $480^{\mathrm{ab}}$ & 874 & $1.82^{\mathrm{c}}$ & $1511^{\mathrm{bc}}$ & $2330^{\mathrm{c}}$ & $1.54^{\mathrm{c}}$ \\
\hline Low energy & $298^{\mathrm{a}}$ & $408^{\mathrm{a}}$ & $1.37^{\mathrm{a}}$ & $834^{\mathrm{a}}$ & $1259^{\mathrm{a}}$ & $1.51^{\mathrm{a}}$ & $461^{\mathrm{b}}$ & 873 & $1.89^{\mathrm{a}}$ & $1593^{\mathrm{a}}$ & $2540^{\mathrm{a}}$ & $1.59^{\mathrm{a}}$ \\
\hline Low energy $+x y l a m$ & $243^{c}$ & $318^{\mathrm{c}}$ & $1.31^{\mathrm{c}}$ & $818^{\mathrm{ab}}$ & $1173^{\mathrm{b}}$ & $1.43^{\mathrm{c}}$ & $500^{\mathrm{a}}$ & 907 & $1.82^{\mathrm{c}}$ & $1560^{\mathrm{ab}}$ & $2398^{b c}$ & $1.53^{\mathrm{c}}$ \\
\hline $\begin{array}{l}\text { Low energy } \\
\text { +amycozyme }\end{array}$ & $242^{\mathrm{c}}$ & $316^{\mathrm{c}}$ & $1.31^{\mathrm{c}}$ & $784^{\mathrm{c}}$ & $1129^{\mathrm{b}}$ & $1.44^{\mathrm{c}}$ & $497^{\mathrm{a}}$ & 902 & $1.82^{\mathrm{c}}$ & $1523^{\mathrm{bc}}$ & $2347^{\mathrm{c}}$ & $1.54^{\mathrm{c}}$ \\
\hline Overall means & 254 & 338 & 1.32 & 799 & 1166 & 1.46 & 486 & 893 & 1.84 & 1540 & 2397 & 1.55 \\
\hline SE of means & \pm 6.19 & \pm 6.99 & \pm 0.01 & \pm 5.92 & \pm 12.77 & \pm 0.01 & \pm 10.8 & \pm 21.42 & \pm 0.01 & \pm 10.22 & \pm 22.16 & \pm 0.01 \\
\hline Significances & $*$ & * & $*$ & $*$ & $*$ & * & $*$ & NS & $*$ & $*$ & $*$ & $*$ \\
\hline
\end{tabular}

a-d Mean within each column with no common superscript differ significantly $(\mathrm{P}<0.05)$.

$* \mathrm{P}<0.05$ NS: not significant 
Table 4. Effect of enzyme supplementation on carcass characteristics of male and female broilers

\begin{tabular}{|c|c|c|c|c|c|c|c|c|c|c|}
\hline \multirow{2}{*}{ Item } & \multicolumn{2}{|c|}{ Dressing \% } & \multicolumn{2}{|c|}{ Liver \% } & \multicolumn{2}{|c|}{ Heart \% } & \multicolumn{2}{|c|}{ Gizzard \% } & \multicolumn{2}{|c|}{ Abdominal Fat \% } \\
\hline & Male & Female & Male & Female & Male & Female & Male & Female & Male & Female \\
\hline Dietary treatments & & & & & & & & & & \\
\hline Control & 73 & 73 & 2.38 & 2.27 & 0.63 & 0.56 & 1.41 & 1.46 & 1.19 & 1.43 \\
\hline Control+ xylem & 73 & 72 & 2.48 & 2.64 & 0.65 & 0.63 & 1.46 & 1.41 & 0.92 & 1.40 \\
\hline Control+amycozyme & 73 & 74 & 2.36 & 2.30 & 0.65 & 0.56 & 1.50 & 1.52 & 0.90 & 1.32 \\
\hline Low energy & 73 & 72 & 2.31 & 2.46 & 0.65 & 0.63 & 1.40 & 1.56 & 1.19 & 1.43 \\
\hline Low energy+ xylam & 73 & 73 & 2.37 & 2.35 & 0.63 & 0.58 & 1.41 & 1.58 & 1.09 & 1.35 \\
\hline Low energy+amycozyme & 73 & 73 & 2.37 & 2.34 & 0.63 & 0.61 & 1.46 & 1.55 & 0.99 & 1.34 \\
\hline Overall means & 73 & 73 & 2.39 & 2.39 & 0.64 & 0.60 & 1.44 & 1.51 & 1.05 & 1.38 \\
\hline SE of means & \pm 0.17 & \pm 0.26 & \pm 0.04 & \pm 0.03 & \pm 0.01 & \pm 0.01 & \pm 0.01 & \pm 0.02 & \pm 0.05 & \pm 0.03 \\
\hline Significances & NS & NS & NS & NS & NS & $\mathrm{NS}$ & $\mathrm{NS}$ & NS & NS & $\mathrm{NS}$ \\
\hline
\end{tabular}

Mean within each column with no common superscript differ significantly $(\mathrm{p}<0.05)$. NS: not significant 